\title{
THE RELATIONSHIP BETWEEN LEARNING INDEPENDENCE AND UTILIZATION OF LEARNING SOURCES WITH MATHEMATICAL LEARNING OUTCOMES OF STUDENTS SMP MUHAMMADIYAH 1 YOGYAKARTA
}

\author{
Riska Tri Pratiwi ${ }^{a}$, HarinaFitriyani ${ }^{b}$ \\ Program Studi Pendidikan Matematika Universitas Ahmad Dahlan \\ Jalan Ring Road Selatan, Tamanan, Banguntapan, Bantul Yogyakarta \\ ariska.dlabu@gmail.com,
}

\begin{abstract}
This research is motivated by the lack of learning independence and the use of learning resources that occur thus might affect the level of student learning outcomes. The purpose of this study was to determine the presence or absence of positive and significant relationships between learning independence and the use of learning resources with students' mathematics learning outcomes in class VIII of even semester in SMP Muhammadiyah 1 Yogyakarta Academic of 2015/2016. The population in this study was all VIII class students as much 7 classes by total students 212 . The sample was taken with a random sampling technique and derived class VIII B as a class sample with 27 students. Data collection technique used to test techniques to determine the result of mathematics learning outcomes and questioner techniques to determine the learning independence and use of learning resources. Instrument testing used validity and reliability testing. The technic to analysis test which is a test of homogeneity, normality, independent, and linearity test. Analysis of the data for testing hypotheses used correlation analysis and linear regression analysis. The results showed that $F_{\text {count }}=$ 5,608648681 and $F_{\text {table }}=3,40$ so $F_{\text {count }} \geq F_{\text {table }}$ which means there is a positive and significant relationship between learning independence and use of learning resources that occur thus might affect the level of student learning outcomes, with a coefficient of determination $(r)=0,5643728384$ and $\hat{\mathrm{y}}=$ $-23,63+0,49 x_{1}+0,76 x_{2}$. The value of Relatively contribution of $X_{1}=32,645 \%, X_{2}=67,355 \%$ and value of effectively contribution of $\mathrm{X}_{1}=10,398 \%, \mathrm{X}_{2}=21,454 \%$.
\end{abstract}

Keywords: Independence Learning, Use of Learning Resources, Mathematics Learning Outcomes.

\section{INTRODUCTION}

Education can be interpreted as a process with certain methods so that people gain knowledge, understanding, and how to behave by needs. So education is needed for humans because educated people naturally have good behavior. In the present time, globalization and the development of science and technology demands an increase in the quality of education. improving the quality of education can be done by making improvements, changes, and renewal of the factors that influence the success of education. According to Slameto (2010: 54), "Factors that influence learning of many types, but can be classified into two groups, namely external factors, and internal factors." The learning environment at home, peers and the utilization of learning resources including external factors that affect student learning outcomes.

Based on information obtained by interviewing several eighth-grade students of SMP Muhammadiyah 1 Yogyakarta on October 24, 2015, mathematics is still considered a difficult subject, but some students consider mathematics as a normal thing and some like mathematics, they said that they only study when doing homework (PR) and during midterm (UTS) and final semester exams, besides students are not utilizing learning resources such as the internet or library, they only have resources in the form of textbooks for class VIII because they are reluctant to find resources other learning in school. This makes it difficult for students to learn mathematics.

While from an interview with one of the mathematics teachers at SMP Muhammadiyah 1 Yogyakarta on October 24, 2015, information was obtained that there were still many students who obtained low mathematics learning outcomes seen in the midterm (UTS) grade VIII students, this was because students lacked independence in learning, they are still dependent on teachers and friends, and the use of learning resources such as the internet and library is still lacking, besides that when given problems they still have difficulty determining the formula used and have difficulty when working on 
problems that are slightly different from the examples given and have difficulty in understanding problems to follow the solution of the essay problem, this is due to the lack of students understanding the basic concepts of mathematics in the given material.

Mulyasa (2007: 163) states several examples of the benefits of utilizing learning resources include:

a. By reading advertisements, leaflets, brochures, listening to the radio and or seeing advertisements on television we can save money on shopping for goods because they know where to sell goods cheaper.

b. Obtain the necessary facts and inform them to the public, the State, and those who need them.

c. Learn to find answers related to school and personal assignments, for example in the fields of science, history, sports, literature, and fields that are following our interests and concerns.

d. Prepare papers and reports effectively and efficiently.

e. Familiarize yourself with learning, anywhere and anytime, and give examples to the community about the importance of learning, which in turn leads to the creation of a learning community.

The results of the exposure to the conditions of the Muhammadiyah 1 Yogyakarta Junior High School students above are supported by the mathematics scores data of the odd semester 2015/2016 academic year which explains that the mathematics learning outcomes of the VIII grade students of SMP Muhammadiyah 1 Yogyakarta are still low. The number of students with an average grade below the KKM is 157 students out of 212 students. Therefore, by researching the factors that influence learning it is expected to benefit students, teachers, parents, and schools.

This research aims to find out whether there is a positive and significant relationship between learning independence and the use of learning resources with mathematics learning outcomes for students of class VIII Even Semester SMP Muhammadiyah 1 Yogyakarta 2015/2016 Academic Year.

\section{METHODS}

The research design used is as follows:

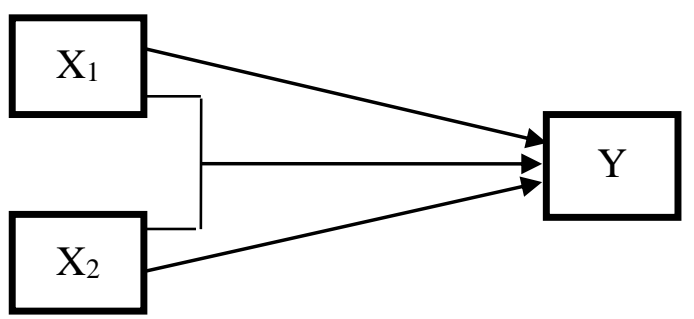

Picture I. Schema of the Relationship between the independent variable and the dependent variable

Information :

$\mathrm{X}_{1} \quad$ : Independence Learning

$\mathrm{X}_{2} \quad$ : Use of Learning Resources

Y : Student Learning Outcomes of Class VIII

The study was conducted at SMP Muhammadiyah 1 Yogyakarta. Held during the even semester of the academic year 2015/2016 in class VIII SMP Muhammadiyah 1 Yogyakarta, in May. The population in this study were eighth-grade students of SMP Muhammadiyah 1 Yogyakarta in Even Semester Academic Year 2015/2016 which consisted of seven classes, namely class VIII A, VIII B, VIII C, VIII D, VIII E, VIII F, VIII G with the total number of students 212 students.

In this study the sampling was done using random sampling technique that is after random sampling using the class drawing, it turns out that the first draw of the class taken as a research sample is class VIII B with the number of students 27 and the second draw of the class taken as a trial is a class VIII D with the number of students 32. The techniques used to collect data in this study are questionnaires and tests. Before being used to reveal the actual data, the instrument was tested in the pilot class to know the validity and reliability of the instrument or in other words to identify problems 
that were weak or flawed. According to Suharsimi Arikunto (2013: 211-212), an instrument is said to be valid if it can measure what is desired.

The analysis test used in this study is a prerequisite test in the form of a homogeneity test, normality test, independent test and linearity test, and hypothesis testing. To test the hypothesis, it uses simple linear regression analysis and multiple linear regression tests. Information about homogeneity test, normality test, independent test and linearity test is as follows:

a. Homogeneity Test

The homogeneity test is a requirement for all differences in hypothesis testing, the goal is to do a homogeneity test to see the categories in the variables have equal variance (equal/homogeneous). Homogeneity test data serves to provide confidence that a set of data in a series of analyzes indeed come from populations that are not much different. Homogeneity tests are of two kinds, namely homogeneity for two populations and homogeneity tests for populations of more than two. Test two populations of homogeneity using the $\mathrm{F}$ test, while for populations of more than two the Bartlet test is used. Bartlet test itself is of two kinds, namely the same sample size and the sample size is not the same.

b. Normality test

A normality test is used to determine whether the data used is normally distributed or not. The formula used is the Chi-Square formula

c. Independent Test

Independence test is used to find out whether or not there is a relationship between the independent variable of learning independence $\left(\mathrm{X}_{1)}\right.$ and the learning resource utilization variable $\left(\mathrm{X}_{2}\right)$, namely by using the formula:

d. Linearity Test

$$
\chi^{2}=\sum_{i=1}^{b} \sum_{j=1}^{k} \frac{\left(O_{i j}-E_{i j}\right)^{2}}{E_{i j}}
$$

Linearity Test is used to determine the relationship between independent variables and dependent variables is linear or not. The test statistics used are:

$$
F_{\text {stat }}=\frac{R J K_{T C}}{R J K_{E}}
$$

\section{RESULTS AND DISCUSSION}

The results of the analysis of the learning independence questionnaire and student learning outcomes test showed that the highest learning independence questionnaire score was 92 . If you look at the results of the mathematics learning test, respondents who had the highest learning independence questionnaire scores obtained high mathematics learning test results, namely also 100 . While the questionnaire scores The lowest learning independence was 69 , and if you look back at the results of the mathematics learning test, respondents who had a low enough learning independence questionnaire got a math learning test result of 75 . Besides, some respondents had a high enough learning independence questionnaire but their learning outcomes low, for example, some respondents have a questionnaire score of 89 but their learning outcomes get a low score of 55. Besides, some respondents have a low score of learning independence questionnaire but learning outcomes are quite high, for example, are respondents who have a questionnaire score of 70 while the score $h$ the learning outcome is 75 . These things are possible because of several other learning factors not discussed in this study. Based on the things that have been explained above, it can be concluded that high learning independence arises in the hearts of the students themselves and the training of parents who accustom their children to independent learning so that students have achieved in learning.

From the results of the questionnaire score analysis of learning resource utilization, it was found that the statement item that had the lowest score was the statement number 12 which reads 'I am not looking for a mathematical problem solving with the help of a math textbook or calculator'. From this, it can be seen that many students do not use books or calculators when searching for information to 
solve math problems. While the item statement that has the highest score is item number 3 which reads 'I am interested in learning mathematics when learning to use the internet'. This shows that most students have been interested in learning mathematics, but when only using textbooks but using the school's internet when math class takes place.

Based on the results of the questionnaire utilization of learning resources, the highest score of questionnaire utilization of learning resources is 95 owned by respondents with high learning outcomes that are 100, while the lowest score of learning resource utilization questionnaire is 67 owned by respondents with quite low learning outcomes namely 55. Same as the case The previous questionnaire and learning outcomes, the results of the questionnaire analysis of the use of learning resources also showed that respondents had a high enough questionnaire score but the learning outcomes were low, for example, respondents with a total questionnaire score of 89 while learning outcomes were 60 . Likewise vice versa with the example respondents who have a questionnaire score of 70 while learning outcomes are 85 . This may be caused by several other learning factors not mentioned in this study.

According to Mulyasa (2007: 156) "Learning resources are all things that can provide convenience to students in obtaining the amount of information, knowledge, experience, and skills needed." Therefore to facilitate students learning to understand science, students need to utilize maximum available learning resources. Seeing the condition of the students who had previously been presented, students of class VIII B of SMP Muhammadiyah 1 Yogyakarta had not made maximum use of the learning resources. Therefore it can be concluded that the use of learning resources influences student learning outcomes.

The results of the analysis of student learning outcomes tests have shown that there are some items that most children do not answer correctly namely items number 20, 24 and 25 . Item number 20 is a matter of story that discusses the surface area of the prism, while items numbers 24 and 25 are questions about pyramid wake height and pyramid wake volume. This is possible because most students do not understand the material about the surface area and volume of the building, especially the construction of prisms and pyramids. Therefore, for the next learning of building space, teachers are expected to be able to explain more about the concept of building space, especially pyramid to students and provide guidance on how to deal with stories about the material, so students can more easily solve problems related to surface area and volume build a pyramid prism in everyday life.

The things that have been explained above, can be explained through linear relationships $\hat{\mathrm{y}}=-$ $23,63+0,49 x_{1}+0,76 x_{2}$. This means that every increase of one unit $\mathrm{X} 1$ results in 0.49 increase in $\mathrm{Y}$ and every increase in one unit $\mathrm{X} 2$ results in 0.76 increase in $\mathrm{Y}$, in other words, if the relationship of learning independence and the use of learning resources is getting better, the learning outcomes of mathematics will increase. Student mathematics learning outcomes are influenced by learning independence and the use of learning resources by $31.852 \%$ while $68.148 \%$ are influenced by other factors not discussed in this study. Of the two variables in this study, the greatest effective contribution was the variable in the use of learning resources (X2), but there was only a small difference between the effective contributions of the two variables.

After it is known that the independence of learning and the use of learning resources has a positive and significant effect on mathematics learning outcomes, this means that the increase and decrease in student mathematics learning outcomes are related to the independence of learning and the use of learning resources. Therefore it is expected that various parties can optimize their role in improving student mathematics learning outcomes.

\section{CONCLUSION}

Based on the results of the research and discussion above, the following research conclusions can be drawn:

1. There is a positive and significant relationship between learning independence with mathematics learning outcomes for students of class VIII in the even semester of SMP Muhammadiyah 1 Yogyakarta 2015/2016 Academic Year. This is indicated by test (t), with $t_{\text {count }}>t_{\text {table }}$ that is 
$2,158380441>1,7081$. Simple correlation coefficient (r) between the learning environment at home $\left(\mathrm{X}_{1}\right)$ with mathematics learning outcomes $(\mathrm{Y})$ of 0.3963260589 with linear regression equations $\hat{\mathrm{y}}=15,49+0,75 x_{I}$.

2. There is a positive and significant relationship between the use of learning resources and mathematics learning outcomes for students of class VIII in the even semester of SMP Muhammadiyah 1 Yogyakarta 2015/2016 This is indicated by test (t), with $t_{\text {count }}>t_{\text {table }}$ that is $2,937324777>1,7081$. Simple correlation coefficient ( $r$ ) between peers (X2) with mathematics learning outcomes $(\mathrm{Y})$ of 0.5065265854 with linear regression equations $\hat{\mathrm{y}}=3,83+0,92 x_{2}$.

3. There is a positive and significant relationship between learning independence and the use of learning resources with mathematics learning outcomes for students of class VIII in the even semester of SMP Muhammadiyah 1 Yogyakarta 2015/2016 Academic Year. This is indicated by the F test, with $F_{\text {count }} \geq F_{\text {table }}$ that is 5,608648681 $\geq 3,40$. The multiple correlation coefficient (r) of 0.5643728384 with the linear regression equation $\hat{y}=-23,63+0,49 x_{1}+0,76 x_{2}$. The relative contribution of $\mathrm{X} 1$ is $32.645 \%$ and $\mathrm{X} 2$ is $67.335 \%$ and the amount of effective contribution $\mathrm{X} 1$ is $10.398 \%$ and $\mathrm{X} 2$ is $21.454 \%$.

\section{REFERENCES}

Arikunto, Suharsimi. 2013. Dasar-Dasar Evaluasi Pendidikan. Jakarta: Rineka Cipta. 2012. Prosedur Penelitian: Suatu Pendekatan Praktik. Jakarta: Rineka Cipta.

Kompetensi dan Sertifikasi Guru.Bandung: PT. Remaja Rosdakarya

Mujiman, Haris. 2011. Manajemen Pelatihan Berbasis Belajar Mandiri. Yogyakarta: Pusaka Pelajar Nurhayati, Eti. 2011. Bimbingan Konseling \& Psikoterapi Inovatif. Yogyakarta: Pustaka Belajar. Praswoto, Andi. 2012. Pengembangan Sumber Belajar. Yogyakarta: PT. Pustaka Insan Madani diakses pada tanggal 13 Maret 2016 12:11.

Sanjaya, Wina. 2013. Perencanaan \& Desain Sistem Pembelajaran. Jakarta.Prenadamedia Group.

Sugiyono. 2009. Statistika untuk Penelitian. Bandung: Alfabeta. .2010.Metode Penelitian Pendidikan : Pendekatan Kuantitatif, Kualitatif, dan R\&D. Bandung : Alfabeta

Suparman. 2012. Metodologi Penelitian Pendidikan. Yogyakarta: MIPA UAD Press 